\title{
Znaczenie kosztów transakcyjnych dla ekspansji zagranicznej przedsiębiorstw
}

\author{
Katarzyna Bentkowska*
}

\begin{abstract}
Autorka analizuje rolę, jaka odgrywaja koszty transakcyjne w zagranicznej ekspansji przedsiębiorstw. Koszty transakcyjne nie sa wyodrębniane w przedsiębiorstwach i często zarzadzajacy nie uświadamiaja sobie ich wysokości. Tymczasem ksztattowanie tej kategorii kosztów może wplywać na wynik ekspansji. Jest ono uzależnione od czynników zwiazanych z ograniczona racjonalnościa podmiotów, oportunizmem, specyficznościa zaangażowanych aktywów, niepewnościa i częstotliwościa zawierania transakcji. Oddziatywanie tych czynników staje sie silniejsze, gdy przedsiębiorstwo wchodzi na rynek zagraniczny. Gtównych źródet wzrostu kosztów transakcyjnych można upatrywać w rosnacym dystansie psychicznym oraz w większej niepewności prowadzenia dziatalności na rynku zagranicznym. Koszty transakcyjne sa silnie zwiazane z czesto analizowanymi barierami rozwoju ekspansji, ponieważ ich pokonywanie wymaga ponoszenia wysokich kosztów.
\end{abstract}

Słowa kluczowe: koszty transakcyjne, zagraniczna ekspansja, niepewność, dystans psychiczny.

Nadesłany: 06.05.2015 | Zaakceptowany do druku: 09.08.2015

\section{Transaction cost in enterprises' international expansion}

The article analyses the transaction cost influence on enterprises international expansion. Enterprises do not separate transaction costs and often are not fully aware of their value. However this cost category may highly influence the outcome of their international expansion. It depends on factors connected with bounded rationality, opportunism, assets specificity, uncertainty and transaction frequency. The influence of these factors becomes more severe as the enterprise enters foreign markets. The main reasons responsible for transaction costs' growth seem to be connected with increasing psychic distance and growing uncertainty of operating in foreign markets. Transaction cost are highly associated with often analyzed expansion barriers as overcoming these barriers incurs bearing high transaction cost.

Keywords: transaction cost, international expansion, uncertainty, psychic distance.

Submitted: 06.05.2015 | Accepted: 09.08.2015

JEL: D8, D23, F14

* Dr Katarzyna Bentkowska - Szkoła Główna Handlowa, Instytut Rynków i Konkurencji. Mailing address: ul. Prowansji 9, 05-500 Józefosław. 


\section{Wstęp}

Koszty transakcyjne odgrywają coraz ważniejszą rolę w działaniu przedsiębiorstw. Globalizacja i narastająca złożoność gospodarki sprawiają, że są one konfrontowane $\mathrm{z}$ rosnącym napływem różnorodnych informacji, zwiększającą się anonimowością na rynku i rosnącą niepewnością. Oczywiście w gospodarce nastąpiły także zmiany umożliwiające przedsiębiorstwom obniżanie kosztów transakcyjnych. Na przykład rozwój nowych kanałów komunikacji i szerokie wykorzystanie Internetu pozwalają na szybszy i tańszy dostęp do partnerów. W ostatecznym bilansie działanie czynników prowadzących do ich wzrostu jest silniejsze. D.C. North zauważa, że choć obserwujemy spadek kosztów produkcji, to w miarę rozwoju społeczeństwa koszty transakcyjne związane z ekonomiczną aktywnością wzrastają (North, 1994).

Koszty transakcyjne nie są wyodrębniane $\mathrm{w}$ przedsiębiorstwach i często zarządzający nie uświadamiają sobie ich wysokości. Zwraca na to uwagę np. W. Szymański, pisząc, że w praktyce gospodarczej świadomość roli kosztów transakcyjnych jest wciąż mała. Mimo słabej świadomości, rośnie jednak ich praktyczny wpływ na wiele decyzji przedsiębiorstw (Szymański, 2011). Koszty transakcyjne są trudne do oddzielenia do innych kosztów przedsiębiorstwa. Ponadto kategoria ta obejmuje nie tylko wymierne koszty finansowe przeznaczane na zawieranie transakcji (np. weryfikacja partnera przez wywiadownię gospodarczą), ale też czas poświęcany na różne czynności przy zawieraniu transakcji (np. poszukiwanie partnerów). Analizowanie kosztów transakcyjnych wiąże się więc z poważnymi problemami, ponieważ duża ich część ma charakter niewymierny. Ponadto w literaturze nie opracowano jednolitego podejścia do istoty kosztów transakcyjnych, powszechnie akceptowanej definicji, klasyfikacji elementów ani metodologii pomiaru. Utrudnia to prowadzenie badań i wyciąganie dających się porównywać wniosków. Tymczasem posiadanie świadomości istnienia tej ukrytej często kategorii kosztów i podejmowanie prób ich kształtowania mogą wpływać na sukces przedsiębiorstwa. S. Kasiewicz zwraca uwagę, że „zanim przedsiębiorcy zdecydują się utworzyć przedsiębiorstwo, powinni wiedzieć o istnieniu kategorii kosztów transakcyjnych" (Kasiewicz, 2004).
W ostatnich latach obserwujemy wzrost zainteresowania teorią kosztów transkacyjnych. Nadal jednak w rzeczywistych procesach decyzyjnych dochodzi do fragmentarycznych i wybiórczych zastosowań tej koncepcji (Gorynia i Mroczek, 2013).

Kształtowanie kosztów transakcyjnych staje się szczególnie ważne w momencie, gdy przedsiębiorstwo podejmuje decyzję o rozszerzeniu działalności poza rynek krajowy. Proces internacjonalizacji wiąże się z koniecznością ponoszenia wyższych kosztów transakcyjnych niż w przypadku działania jedynie na rynku krajowym, a ich optymalizowanie może wpłynąć na powodzenie ekspansji zagranicznej.

Teoria kosztów transakcyjnych stanowi ważną perspektywę, pozwalającą analizować międzynarodową ekspansję przedsiębiorstw (Hennart, 2010). Koncepcja ta jest powiązana z klasycznymi teoriami zagranicznej ekspansji przedsiębiorstw, np. $\mathrm{z}$ teorią internalizacji czy paradygmatem OLI. Ekspansja jest tu wyjaśniana m.in. kształtowaniem kosztów transakcyjnych i ich wpływem na włączanie do przedsiębiorstw kolejnych transakcji na rynku międzynarodowym (Rymarczyk, 2004). Dzięki internacjonalizacji przedsiębiorstwa mogą unikać pewnych kosztów transakcyjnych, ponieważ nie wykorzystują mechanizmu rynkowego. Nie oznacza to oczywiście, że w związku z rozwojem ekspansji unikną one dodatkowych kosztów wynikających z podjęcia działalności na zagranicznym rynku.

Rola kosztów transakcyjnych w ekspansji zagranicznej jest też widoczna w wielu badaniach empirycznych $\mathrm{z}$ tego zakresu. Jednym $\mathrm{z}$ najczęściej podejmowanych tu tematów jest wykorzystanie teorii kosztów transakcyjnych do wyboru odpowiedniej z ekonomicznego punktu widzenia formy ekspansji zagranicznej (Gorynia i Mroczek, 2013). Liczne badania pokazują, że kształtowanie kosztów transakcyjnych wpływa na wybór formy wejścia na rynek zagraniczny (np. Klein, Frazier i Roth, 1990; Peng i York, 2001; Geyskens, Steenkamp i Kumar, 2006; Hennart, 2010a; Mroczek 2014). Wybór odpowiedniej formy ekspansji wpływa niewątpliwie na szanse jej powodzenia. Badania pokazują np., że firmy, które wykorzystują formy wejścia wynikające $\mathrm{z}$ analizy kosztów transakcyjnych osiągają lepsze wyniki - zarówno finansowe, jak i niefinansowe (np. Brouthers, 2002). Zwraca się jednak uwagę, że mimo rozwoju 
badań w tym zakresie, w literaturze nadal brakuje narzędzi pozwalających zarządzającym na wybór odpowiednich form wejścia (Brouthers, 2013).

Rola kosztów transakcyjnych może zaznaczać się także na etapie rozpoczynania ekspansji oraz przy podejmowaniu decyzji o ewentualnym wzroście zaangażowania w działanie na zagranicznych rynkach. Gdy przedsiębiorstwa chcą uniknąć wzrostu ponoszonych kosztów transakcyjnych, mogą zrezygnować $\mathrm{z}$ wejścia na nowe rynki lub silnie ograniczyć zaangażowanie w internacjonalizację. Koszty transakcyjne mogą więc stanowić barierę ekspansji. Modele opisujące rozwój internacjonalizacji nie poruszaja wyraźnie kwestii związanych z nią kosztów (Eriksson, Johanson, Majkgard i Sharma, 1997), w tym oczywiście kosztów transakcyjnych. Tymczasem ich postrzeganie przez przedsiębiorstwa może wywierać znaczący wpływ na przebieg tego procesu.

Celem opracowania jest pokazanie roli, jaką kształtowanie kosztów transakcyjnych odgrywa w ekspansji przedsiębiorstw w kontekście barier internacjonalizacji.

\section{Koncepcja kosztów transakcyjnych}

Pojęcie kosztów transakcyjnych jest stosunkowo nowe. Początkowo pojawiło się ono w ekonomii monetarnej w odniesieniu do wyjaśniania motywów trzymania przez podmioty gospodarcze pieniądza, zamiast przynoszących większe zyski innych aktywów kapitałowych (Klaes, 2000). Wzrost zainteresowania koncepcją kosztów transakcyjnych i jej szerokie wykorzystanie w nowej ekonomii instytucjonalnej zapoczątkował R. Coase. Zwrócił on uwagę na występowanie kosztów działania „mechanizmu cenowego" związanych $z$ organizacją i koordynacją transakcji i ich wpływu na sposób zawierania transakcji (Coase 1937). Jeśli koszty organizacji transakcji na rynku przewyższają koszty jej organizacji wewnątrz przedsiębiorstwa, występuje ekonomiczne uzasadnienie dla jego powstania lub powiększenia. Przedsiębiorstwo może być powiększane jedynie do określonych granic, ponieważ po przekroczeniu pewnej wielkości bardziej efektywne dla kosztów transakcyjnych będzie zorganizowanie kolejnych transakcji na rynku.

R. Coase nie wykorzystał samego pojęcia „koszty transakcyjne” ani go nie zoperacjo- nalizował (Klaes, 2000a). W efekcie przez kilkadziesiąt kolejnych lat koncepcja ta nie była szerzej wykorzystywana (Hardt, 2006). Do jej upowszechnienia przyczyniły się prace O.E. Williamsona, który w latach 70. XX w. odwołał się do kwestii sposobów organizacji transakcji i kosztów transakcyjnych.

Inne podejście do pojęcia kosztów transakcyjnych można spotkać $\mathrm{w}$ pracach związanych z prawami własności, gdzie A. Alchian i H. Demsetz akcentowali rolę kosztów transakcyjnych w ustanawianiu i egzekwowaniu praw własności. Zwracali też uwagę na występowanie kosztów pomiaru zaangażowania podmiotów wykonujących transakcję, czyli monitorowania wysiłku (Alchian i Demsetz, 1972).

W miarę rozwijania koncepcja kosztów transakcyjnych zyskiwała na znaczeniu i była stosowana w różnych badaniach. $\mathrm{Z}$ przeglądu badań wynika, że była ona wykorzystywana nie tylko w obszarach związanych $\mathrm{z}$ ekonomią, takich jak teoria organizacji, rachunkowość, finanse, marketing czy biznes międzynarodowy, ale także w naukach politycznych, społecznych, prawnych (Richman i Macher, 2006).

Szerokie wykorzystanie tej koncepcji jest nadal utrudniane przez problemy interpretacyjne. Koszty transakcyjne rozumiane sa ogólnie jako koszty wynikające $\mathrm{z}$ niedoskonałości rynku, jednak dotychczas nie została wypracowana powszechnie akceptowana definicja tego pojęcia (Wang, 2003). D.C. North pod tym pojeciem rozumie koszty określania cech wymienianych dóbr, ochrony praw własności oraz zabezpieczania i egzekwowania umów (North, 1994a). Z kolei O.E. Williamson określa je jako względne koszty planowania, przystosowania i monitorowania wykonania transakcji przy wykorzystaniu różnych struktur zarządzania transakcją (Williamson, 1989).

Definicje spotykane w literaturze są jednak dość ogólne, co utrudnia operacjonalizację i prowadzi do zaliczania do tej kategorii różnych rodzajów kosztów.

Dla lepszego wyjaśnienia znaczenia kosztów transakcyjnych dla przedsiębiorstw warto przytoczyć kilka klasyfikacji pokazujących, na jak wielu płaszczyznach powstają te koszty.

Jeżeli chodzi o przyczyny powstawania, można wyróżnić koszty koordynacji i motywacji (Milgrom i Roberts, 1992).

Koszty koordynacji - koszty czynności, które przedsiębiorstwo musi podjacć, 
by zawrzeć umowę. Składają się na nie zarówno koszty związane $\mathrm{z}$ poszukiwaniem partnerów, jak i koszty negocjowania umów, ustalania warunków transakcji i ich realizacji. Są to więc m.in. koszty nawiązania kontaktów między stronami, rozpowszechniania informacji o ofercie firmy, znalezienia odpowiedniej oferty, pozyskania różnorodnych informacji o warunkach rynkowych, poznania i realizacji prawa, przeprowadzenia badań mających na celu np. poznanie gustów klientów. Do kosztów koordynacji należą także koszty wykorzystania usług różnego rodzaju firm doradczych czy koszty związane z wymianą walut.

Moga być tu zaliczone także utracone korzyści z powodu nieznalezienia optymalnej oferty i rezygnacji z zawarcia transakcji. Poszukujące odpowiednich ofert podmioty ponoszą często znaczące koszty i mogą zrezygnować z poszukiwania optymalne transakcji. Decydując się na zawarcie mniej korzystnej transakcji, tracą przy tym potencjalne korzyści (Milgrom i Roberts, 1992a).

Koszty motywacji - koszty czynności, które przedsiębiorstwo musi podjaćc, aby zabezpieczyć się przed skutkami występowania asymetrii informacji, zachowań oportunistycznych i niedoskonałości umów.

Niekompletność i asymetria informacji powodują, że strony transakcji nie dysponują wiedzą pozwalającą na określenie, czy warunki umowy są dla nich akceptowalne (np. właściciel używanego samochodu zna jego wady i zalety, a potencjalny nabywca samochodu ma trudności ze zweryfikowaniem jego oferty). Obawa przed zachowaniami oportunistycznymi może doprowadzić do ustalenia kosztownych zabezpieczeń, a nawet do rezygnacji z zawierania transakcji. Umowy są niedoskonałe i niekompletne, co wynika $\mathrm{z}$ faktu, że próba ustalenia w kontrakcie wszystkich możliwych sytuacji i warunków jest najczęściej niemożliwa. Prowadzi to do zwiększenia niepewności stron co do osiągnięcia zaplanowanego efektu.

Koszty motywacji obejmują więc m.in. koszty związane $\mathrm{z}$ weryfikowaniem wiarygodności partnerów, korzystaniem z usług wywiadowni gospodarczych, zabezpieczaniem transakcji (np. poprzez zawieranie umowy w formie notarialnej), wykupywaniem ubezpieczeń.

Druga klasyfikacja kosztów transakcyjnych uwzględnia płaszczyzny ich powstawania. Zgodnie z nią wyróżniamy koszty prowadzenia wymiany poprzez rynek (tzw. koszty rynkowe) oraz koszty koordynacji działania firmy (tzw. koszty zarządzania). Przykładem kosztów rynkowych mogą być koszty znalezienia partnera, natomiast koszt zarządzania stanowi np. szkolenie pracowników, ich nadzorowanie. Do kosztów transakcyjnych zaliczane są jeszcze tzw. koszty polityczne związane $z$ tworzeniem, utrzymaniem, wykorzystaniem i zmianami instytucji (Furubotn i Richter, 2005). Przykładem mogą tu być koszty wprowadzenia pewnego przepisu. Dla wyboru optymalnej formy zarządzania transakcją konieczne jest jednoczesne analizowanie zmian rynkowych kosztów transakcyjnych i wewnętrznych kosztów zarządzania (Hennart, 2010b).

Kolejna klasyfikacja wyróżnia koszty transakcyjne w zależności od momentu ich powstawania, tj. koszty ex ante i koszty ex post.

Pierwszy rodzaj obejmuje koszty doprowadzenia do zawarcia umowy, a więc koszty poszukiwania informacji, koszty negocjacji i podjęcia decyzji. Do drugiego rodzaju zaliczane są koszty monitorowania i egzekucji umowy (Rao, 2003). Te dwie kategorie kosztów są powiązane, co powoduje, że obniżając jedną z nich, należy uwzględnić efekty, jakie taka decyzja wywrze na całkowite koszty (np. już przy ustalaniu umowy strony podejmują próby ochronienia się przed oportunistycznym zachowaniem partnera i jeśli nie ustala odpowiednich zabezpieczeń ex ante, będą zmuszone ponosić większe koszty monitorowania i egzekucji umowy ex post).

\section{Koszty transakcyjne $\mathrm{w}$ internacjonalizacji}

\section{1. Źródła powstawania kosztów transakcyjnych $w$ internacjonalizacji}

W literaturze często podkreśla się, że koszty transakcyjne związane $\mathrm{z}$ działaniem na rynkach zagranicznych są wyższe niż koszty działania w kraju (Czinkota, 1996). Choć teoria kosztów transakcyjnych w tradycyjnym ujęciu nie porusza kwestii internacjonalizacji, można w niej szukać przyczyn wzrostu kosztów transakcyjnych w przedsiębiorstwach wchodzących na rynki zagraniczne.

O.E. Williamson, wśród czynników kształtujących koszty transakcyjne, wymie- 
Rysunek 1. Czynniki wpływające na kształtowanie kosztów transakcyjnych

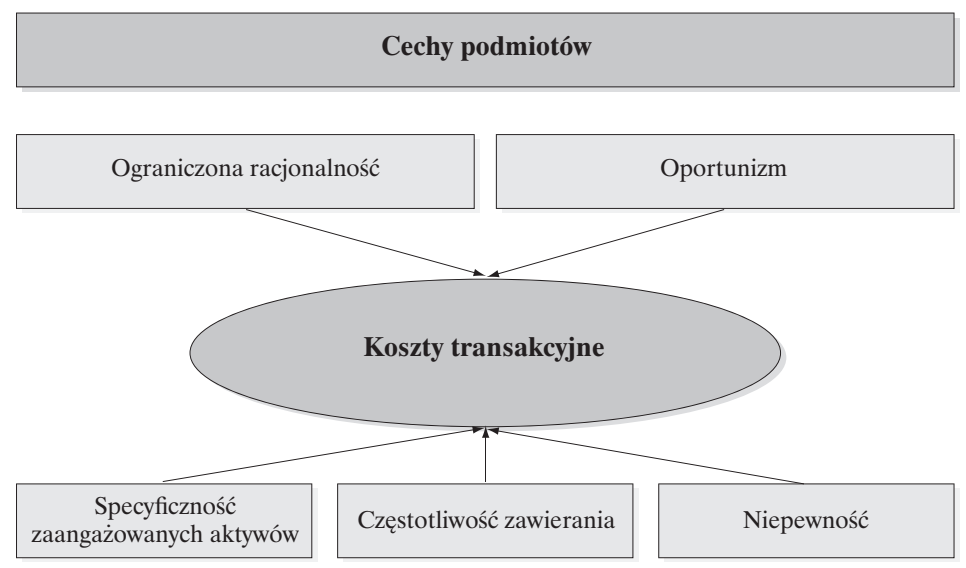

Cechy zawieranych transakcji

Źródło: opracowanie własne na podstawie: Williamson (1998, s. 56-64).

nia czynniki związane $\mathrm{z}$ podmiotami tj. ograniczoną racjonalność i oportunizm oraz czynniki związane $\mathrm{z}$ charakterem zawieranych transakcji, tj. specyficzność zaangażowanych aktywów, częstotliwość zawierania transakcji oraz niepewność (Williamson, 1998).

Ograniczona racjonalność podmiotów powodowana jest brakiem dostępu do informacji, ich skomplikowaniem oraz trudnościami w przetwarzaniu (Rao, 2003a). Podmioty, w momencie podejmowania decyzji, mają dostęp do ograniczonej wiedzy, a zdobycie dodatkowych informacji wymaga poniesienia kosztów. Nawet jeśli dany rodzaj informacji jest dostępny, konieczne staje się rozważenie, czy jest to opłacalne i czy prowadzi do zwiększenia efektywności działania. Ponadto w przypadku pozyskania zbyt dużej ilości informacji, nie będzie możliwe ich wykorzystanie i przychody z informacji spadną (Arrow, 1985).

Oportunizm oznacza dążenie ludzi do realizacji własnych interesów i szukanie doraźnych osobistych korzyści. Zachowania oportunistyczne wiążą się najczęściej $\mathrm{z}$,subtelnymi formami podstępu”, mogą jednak obejmować także oszustwo, kłamstwo czy kradzież (Williamson, 1998). Oportunizm powoduje, że strony transakcji staraja się minimalizować swój wkład, co zwiększa niepewność co do rezultatu ich działań. Groźba wystąpienia zachowań oportunistycznych wymusza konieczność monitorowania stron transakcji. Postępujące w sposób oportunistyczny podmioty ujawniają informacje w sposób niekompletny lub zniekształcony, dążąc do zatajenia i pogmatwania rzeczywistego obrazu sytuacji. Dotyczy to przede wszystkim informacji na temat podejmowanego wysitku własnego.

Specyficzność zaangażowanych w transakcję aktywów wpływa na poziom kosztów oraz na poziom ryzyka związanego z zachowaniem oportunistycznym. Jeśli jedna ze stron transakcji dokona inwestycji w wysokim stopniu powiązanych $\mathrm{z}$ daną transakcja (np. kupi specjalistyczny sprzęt), ich wykorzystanie $\mathrm{w}$ innej transakcji będzie trudne lub niemożliwe. W przypadku zerwania umowy strony poniosłyby znaczące straty. Doprowadzenie do zawarcia transakcji wymagającej inwestycji w rzadko spotykane aktywa będzie więc trudniejsze. Przy konieczności zaangażowania w transakcję tego typu aktywów oportunistyczne zachowanie jednej ze stron jest bardziej dotkliwe niż przy transakcjach niewymagających takich inwestycji, np. przy zakupie powszechnie dostępnych towarów (Milgrom i Roberts, 1992).

Częstotliwość zawierania transakcji - gdy transakcja powtarza się często, w podobnych warunkach, strony tworzą 
pewne rutyny ułatwiające doprowadzanie do jej zawarcia. Jeśli natomiast transakcje są nietypowe, partnerzy muszą ustalić dokładne warunki ich przeprowadzenia. Koszty negocjacji i zawarcia kontraktu sa więc niższe przy masowych transakcjach i zawieraniu typowych umów, np. w handlu zbożem, podczas gdy zawarcie kontraktu na zakup specjalistycznych urządzeń pociaga za sobą o wiele większe koszty (Gruszecki, 2002). Duża czestotliwość zawierania transakcji prowadzi do zacieśnienia kontaktów między stronami i nawiązania partnerskich długookresowych więzi. Może to prowadzić nawet do wyeliminowania konieczności zawierania formalnych umów, ponieważ obie strony znają oczekiwania partnerów i mają podstawy, żeby oczekiwać ich realizacji.

Niepewność oznacza sytuacje, kiedy nie są znane ani możliwe scenariusze występujące w przyszłości, ani prawdopodobieństwa ich wystąpienia. Może odnosić się ona do różnorodnych aspektów wpływajacych na działanie podmiotów, np. gustów klientów, warunków produkcji, zmian regulacji (Arrow, 1985). Niepewność połączona z wysokim poziomem skomplikowania transakcji prowadzi do powstania trudności przy negocjowaniu umowy, ponieważ nie jest możliwe dokładne przewidzenie wszystkich przyszłych zdarzeń. W efekcie trudniejsze staje się doprowadzenie do zawarcia umowy i optymalizacja związanych z nią kosztów.

Internacjonalizacja przedsiębiorstwa powoduje zmiany znaczenia zarówno cech podmiotów podejmujących decyzje, jak i cech determinujacych charakter zawieranych transakcji. Odnosząc się do zidentyfikowanych przez Williamsona czynników kształtujących koszty transakcyjne (Williamson, 1998), za główne źródła zwiększenia tych kosztów przy rozpoczęciu ekspansji można uznać:

1. Wzrost trudności w podejmowaniu racjonalnych decyzji - $\mathrm{W}$ miarę zwiększania zaangażowania $w$ internacjonalizację przedsiębiorstwo potrzebuje coraz więsszej ilości informacji. $\mathrm{Na}$ rynku zagranicznym funkcjonują odmienne regulacje prawne, wymagania odnośnie do produktów, zwyczaje handlowe itp., które przedsiebiorstwo musi poznać. Inne sa też oczekiwania klientów, do których trzeba dostosować ofertę. Istotnym czynnikiem utrudnia- jącym działanie na rynku zagranicznym i wymuszajacym pozyskiwanie informacji jest bariera kulturowa i językowa. Informacje stają się więc coraz trudniejsze do zdobycia. Jednocześnie ich przetworzenie i wykorzystanie zaczyna być bardziej skomplikowane. Prowadzi to do zwiększenia odczuwalności ograniczonej racjonalności podmiotów przy podejmowaniu decyzji i wzrostu kosztów.

2. Wzrost niepewności przy rozszerzaniu działalności na zagraniczne rynki - przedsiębiorstwo wchodzi na rynek, którego uwarunkowania są inne niż w kraju, zawiera transakcje $\mathrm{z}$ nowymi klientami, których przyzwyczajenia i gusty mogą być inne niż klientów krajowych. Zostaje także narażone na wystąpienie większej liczby zagrożeń, przed którymi musi się zabezpieczyć. Chodzi tu np. o ryzyko zmiany kursu walutowego, ale też o ogólne ryzyko prowadzenia działalności gospodarczej, związane np. z wprowadzeniem niekorzystnych dla przedsiębiorstwa regulacji na rynku zagranicznym. Jest więc zmuszone do uwzględniania większej ilości zmieniających się czynników, a dodatkowo ograniczona racjonalność powoduje, że jest to trudne. W efekcie działanie na rynku zagranicznym wiąże się ze zwiększoną niepewnością, która prowadzi do wzrostu kosztów transakcyjnych.

3. Wzrost znaczenia potencjalnych zachowań oportunistycznych - rozpoczynając działalność na zagranicznym rynku, przedsiębiorstwo pozyskuje nowych partnerów, których wiarygodność jest trudniejsza do zweryfikowania. Jednocześnie monitorowanie ich działań jest utrudnione przez odległość geograficzną. Ponadto istnienie bariery językowej i kulturowej utrudnia nawiązanie i utrzymanie kontaktów. W przypadku opóźnień w uzyskaniu zapłaty od zagranicznego partnera przedsiębiorstwo ma większe trudności w jej egzekwowaniu i wiążą się $\mathrm{z}$ tym większe koszty. Ryzyko wystapienia zachowań oportunistycznych przy zawieraniu transakcji $\mathrm{z}$ zagranicznym partnerem wzrasta, co pociąga za sobą wzrost kosztów transakcyjnych.

4. Większą specyficzność zaangażowanych w transakcję aktywów - rozpoczęcie ekspansji zagranicznej wiąże się

Wydział Zarządzania UW ～DOI 10.7172/1733-9758.2016.20.2 
z koniecznością podjęcia w przedsiębiorstwie pewnych działań mających na celu dostosowanie firmy i jej produktów do wymagań zagranicznego rynku i zagranicznego klienta. Przykładowo przedsiębiorstwo pozyskuje certyfikaty, tłumaczy instrukcje na języki obce, zmienia produkt, dostosowując go do konkretnych wymagań klienta albo nawet dokonuje inwestycji na rynku zagranicznym. Zerwanie umowy przez zagranicznego partnera po wprowadzeniu tych dostosowań staje się dla niego bardziej dotkliwe.

5. Relatywnie mniejszą częstotliwość zawierania transakcji niż na rynku krajowym - w momencie gdy przedsiębiorstwo rozpoczyna ekspansję na rynki zagraniczne, częstotliwość zawierania transakcji jest niewielka i z reguły, przynajmniej na pierwszym etapie, niższa niż na rynku krajowym. Przedsiębiorstwo nie ma wtedy doświadczenia, nie dysponuje kontaktami z zagranicznymi partnerami, nie ma wypracowanych procedur zawierania transakcji. Jest więc bardziej narażone na ponoszenie wyższych kosztów transakcyjnych. Znaczenie zdobycia takiego doświadczenia potwierdza S. Reid, pisząc, że jeśli firma ma możliwość wystandaryzowania warunków wymiany z partnerem, może zredukować koszty transakcyjne (Reid, 1983). Autor zauważa ponadto, że związane ekspansją koszty transakcyjne mogą odgrywać szczególnie istotną rolę właśnie na etapie rozpoczynania działalności eksportowej.

Powyższa analiza pokazuje, że oddziaływanie wszystkich czynników determinujących kształtowanie kosztów transakcyjnych staje się silniejsze przy rozszerzeniu działalności na rynki zagraniczne i prowadzi do wzrostu kosztów transakcyjnych przedsiębiorstwa.

W literaturze można znaleźć próby wyjaśnienia przyczyn wzrostu kosztów transakcyjnych w ekspansji. Przykładowo

A.M. Abdel-Latif i J. Nugent wyodrębniają dwie grupy przyczyn: różnice językowe, kulturowe, zróżnicowanie gustów klientów, charakter konkurencji, różne regulacje prawne, bariery administracyjne itp. oraz trudności w egzekwowaniu umów zawartych $\mathrm{z}$ zagranicznymi partnerami, wyższe ryzyko nieuzyskania zapłaty (Abdel-Latif i Nugent, 1996). Podobne wyjaśnienie przedstawia Ch. Fischer, wyróżniając: dystans psychiczny i wynikające $\mathrm{z}$ niego większe trudności przy komunikowaniu się z zagranicznym partnerem i negocjowaniu umów oraz wyższe niż w przypadku rynku krajowego ryzyko związane z działaniem na rynkach zagranicznych, wynikające z występowania większej liczby niemożliwych do kontrolowania czynników (Fischer, 2004). L. Kim, J.B. Nugent i S.J. Yhee jako źródła powstawania wyższych kosztów transakcyjnych przy zawieraniu transakcji międzynarodowych wymieniają.: różnice językowe, kulturowe, prawne, różnice dochodów klientów, dostęp do źródeł informacji, charakter konkurencji oraz trudności w egzekwowaniu umów z zagranicznym partnerem (Kim, Nugent i Yhee, 1997).

Bazując na powyższych obserwacjach, można przyjąć założenie, że czynniki wpływające na powstawanie wyższych kosztów transakcyjnych zaliczają się do dwóch grup. Obejmuja one:

- czynniki związane z dystansem psychicznym;

- czynniki związane z większa niepewnością prowadzenia działalności na rynku zagranicznym.

\subsection{Koszty transakcyjne jako bariera zagranicznej ekspansji przedsiębiorstwa}

W badaniach empirycznych nadal niewiele jest analiz pokazujących, jak wzrost kosztów transakcyjnych związanych z działaniem na zagranicznym rynku wpływa na podejście przedsiębiorstw do internacjonalizacji i czy stanowi on istotną bariere ekspansji. Znaczenie kosztów transakcyjnych jako bariery pokazuje np. badanie przyczyn rzadkiego wchodzenia firm ubezpieczeniowych z USA na rynki zagraniczne - za jedną z najważniejszych przyczyn tego zjawiska uznano wysokie koszty transakcyjne (Schroath i Korth, 1989). Podobnie wygląda sytuacja w odniesieniu do eksportu - związane z nim wysokie koszty transakcyjne moga prowadzić do małego zainteresowania przedsiębiorców tego rodzaju działalnością (Abdel-Latif i Nugent, 1996).

Pomocne w analizowaniu znaczenia kosztów transakcyjnych w internacjonalizacji moga być badania dotyczace barier w ekspansji. W literaturze opisywane sa różne rodzaje barier i problem ten jest często podejmowany w badaniach. Różne 
prace zawierają inne ich klasyfikacje przykładowo L.C. Leonidou wyróżnia dwie główne grupy, tj. bariery wewnętrzne i zewnętrzne (Leonidou, 2004):

- bariery wewnętrzne:

- informacyjne (np. brak informacji pozwalających na analizowanie rynku zagranicznego),

- operacyjne (np. ograniczone możliwości poświęcania czasu menedżerów na działalność eksportową, brak środków finansowych na jej podjęcie),

- marketingowe (np. dopełnienie wymogów odnośnie pakowania i znakowania produktów, utrudniony dostęp do kanałów dystrybucji);

- bariery zewnętrzne:

- formalne (np. trudne procedury eksportowe),

- rządowe (np. brak programów wsparcia eksportu),

- środowiskowe (np. bariery taryfowe, ryzyko walutowe).

Nie ma tu odwołania do kosztów transakcyjnych, jednak w praktyce wiele z przedstawionych barier jest $\mathrm{z}$ nimi powiązanych. $\mathrm{Z}$ powstawaniem kosztów transakcyjnych wiążą się takie bariery jak np. trudności $\mathrm{z}$ dostępem do informacji, trudności z nawiazaniem kontaktu z klientami, brak odpowiednich zasobów w przedsiębiorstwie, niezbędne dostosowania do wymogów zagranicznego rynku czy ograniczenia w handlu. Konieczność pokonywania tych barier często pociąga za sobą ponoszenie kosztów transakcyjnych, więc prace potwierdzające rolę barier w ekspansji, pośrednio potwierdzają także ważne znaczenie kosztów transakcyjnych.

Jak dotąd prowadzonych było niewiele badań empirycznych bezpośrednio analizujących koszty transakcyjne jako barierę ekspansji, jednak niektórzy autorzy wspominają czasem o ich związku z kosztami transakcyjnymi. Przykładowo Ch. Fischer, analizując znaczenie kosztów transakcyjnych jako bariery rozwoju eksportu dzieli je na sześć grup obejmujących (Fischer, 2004):

- przeszkolenie pracowników zaangażowanych w działalność eksportową,

- udział w targach,

- problemy z logistyką,

- ustalanie warunków umów eksportowych, prowadzenie dokumentacji związanej z eksportem oraz zarządzanie ryzykiem walutowym,
- pozyskanie informacji o rynkach zagranicznych,

- wsparcie eksportu przez rząd.

Inne grupy barier w eksporcie przestawiaja G. Anastassopoulos i W.B. Traill, którzy także wiążą je z kosztami transakcyjnymi. Jako najważniejsze bariery wymieniają oni (Anastassopoulos i Traill, 1998):

- taryfowe i pozataryfowe ograniczenia handlowe,

- koszty dostosowania produktu do lokalnych wymogów,

- niepewność wynikającą z braku informacji o rynku zagranicznym i potrzebach klientów,

- ryzyko związane z wykorzystaniem pośredników.

W powyższych pracach widać podobieństwa do klasyfikacji barier w zagranicznej ekspansji, co potwierdza, że koszty transakcyjne należy traktować jako barierę eksportu.

Role kosztów transakcyjnych w zagranicznej ekspansji pośrednio potwierdza S. Singh, piszace, że bariery związane ze sprzedażą towarów na rynkach zagranicznych sa inne niż bariery na rynku krajowym (Singh, 1996). Skoro pokonywanie barier wiąże się z ponoszeniem kosztów transakcyjnych, można analogicznie zakładać, że koszty transakcyjne sprzedaży na rynkach zagranicznych będą się kształtować inaczej niż koszty transakcyjne sprzedaży na rynku krajowym.

Do najczęściej pojawiających się w innych badaniach barier w ekspansji zagranicznej związanych z kosztami transakcyjnymi należą: trudności $\mathrm{w}$ znalezieniu partnera (np. Barnes, Chakrabarti i Palihawadana, 2006; Byford i Henneberry, 1996; Leonidou i Katsikeas, 1996), bariera językowa (np. Barker i Kaynak, 1992), brak informacji o rynkach zagranicznych (np. Al-Aali, 1995; Barnes, Chakrabarti i Palihawadana, 2006a), konieczność wprowadzenia pewnych dostosowań w produkcie (np. Barnes, Chakrabarti i Palihawadana, 2006; Leonidou i Katsikeas, 1996a), ryzyko walutowe (np. Byford i Henneberry, 1996a; Al-Aali, 1995a), trudności w zabezpieczeniu otrzymania zapłaty i jej egzekwowaniu (np. Barker i Kaynak, 1992a; Byford i Henneberry, 1996), bariery handlowe (np. Barker i Kaynak, 1992b), brak odpowiednio wykwalifikowanych pracowników (np. Barker i Kaynak, 1992c) czy trudne procedury 
eksportowe (np. Al-Aali, 1995; Leonidou i Katsikeas, 1996).

\subsection{1. Źródła powstawiania kosztów transakcyjnych w eksporcie - wyniki badań}

Ilustracje i uzupełnienie prowadzonej tu analizy mogą stanowić wnioski z badań przeprowadzonych wśród działających w Polsce przedsiębiorstw branży spożywczej prowadzących działalność eksportową ${ }^{1}$ Miały one na celu pokazanie, w jakich obszarach powstają koszty transakcyjne stanowiące główne bariery ekspansji i jakie są ich źródła.

Analizowane w badaniu źródła można odnieść do zidentyfikowanych na podstawie teoretycznych rozważań dwóch głównych grup czynników wpływających na powstawanie wyższych kosztów transakcyjnych przy zawieraniu transakcji na rynku zagranicznym niż na rynku krajowym, tj.:

- czynników związanych z dystansem psychicznym:

- trudności w dostępnie do informacji o rynku zagranicznym,

- trudności w znalezieniu partnera na rynku zagranicznym,

- bariera kulturowa i językowa (trudności w komunikowaniu się z zagranicznym partnerem, inne zwyczaje handlowe itp.),
- odmienne regulacje prawne,

- odmienne gusty klientów,

- konieczność dostosowania produktów do odmiennych wymogów rynku zagranicznego,

- występowanie barier taryfowych,

- skomplikowane procedury/dokumentacja związana z eksportem;

- czynników związanych z większą niepewnością prowadzenia działalności na rynku zagranicznym:

- ryzyko walutowe,

- zwiększone ryzyko prowadzenia działalności na rynku zagranicznym (np. większe ryzyko nieotrzymania zapłaty, trudności w egzekwowaniuzapłaty).

Siła oddziaływania tych źródeł niewątpliwie zależy od obszaru geograficznego, do którego kierowany jest eksport. Różne obszary charakteryzuja się innym natężeniem roli dystansu psychicznego czy ponoszonego ryzyka. W badaniu nie analizowano problemu w rozbiciu na różne rynki eksportowe i takie zróżnicowanie nie będzie tu widoczne.

Przedsiębiorstwa uczestniczace w badaniu ankietowym były proszone o wskazanie głównych źródeł powstawania kosztów transakcyjnych; rozkład ich odpowiedzi przedstawiony został na rysunku 2 .

Najczęściej wskazywane źródło powstawania kosztów transakcyjnych przy prowa-

Rysunek 2. Główne źródła powstawania kosztów transakcyjnych przy prowadzeniu działalności eksportowej-odpowiedzi $w$ \%*

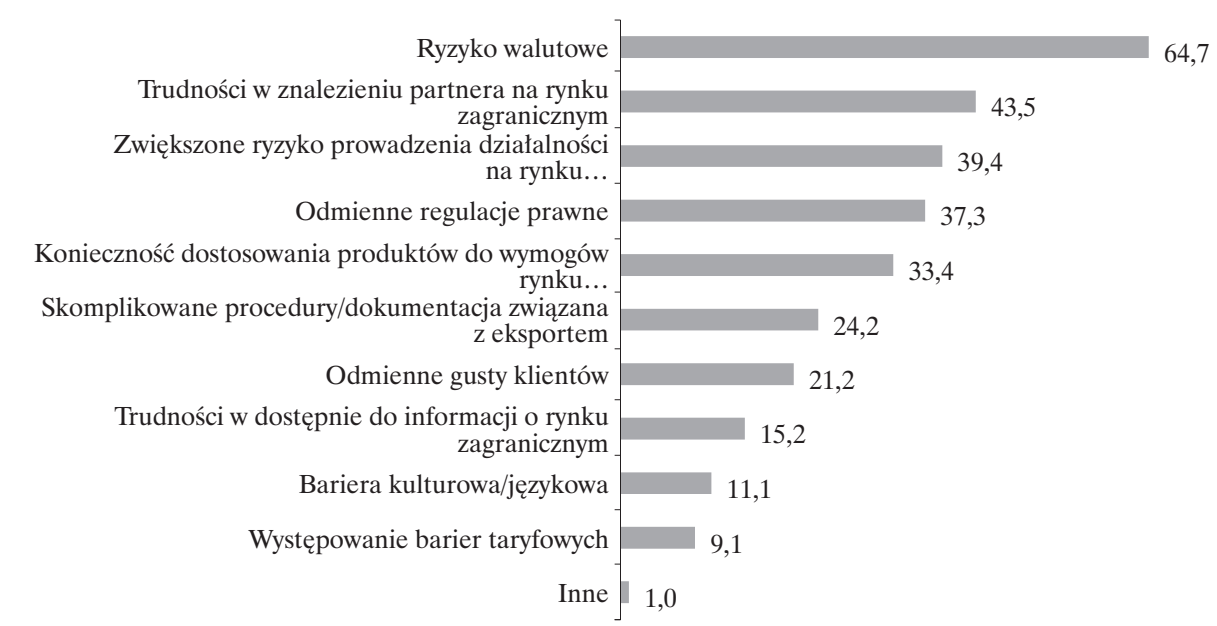

Źródło: opracowanie własne na podstawie wyników badania ankietowego - * każda firma miała wskazać trzy główne przyczyny powstawania kosztów transakcyjnych. 
dzeniu działalności eksportowej stanowi ryzyko walutowe, wybrane przez $64,7 \%$ firm. Wyniki badania pokazują, że wszelkie kwestie związane z ryzykiem stanowią istotne obciążenie dla przedsiębiorstw, ponieważ na trzeciej pozycji znalazło się jeszcze „zwiększone ryzyko prowadzenia działalności na rynku zagranicznym", gromadząc wskazania prawie $40 \%$ firm. Widać więc, że obawa przed ryzykiem, konieczność zabezpieczenia przed nim czy ewentualnie powstające straty znacząco przyczyniają się do powstawania kosztów transakcyjnych. Zwiększone ryzyko przy prowadzeniu działalności na rynku zagranicznym powstaje także w wyniku zachowań oportunistycznych, które są trudniejsze do kontrolowania. Choć w kwestionariuszu zawarte zostały jedynie dwie przyczyny powstawania kosztów transakcyjnych związane $\mathrm{z}$ większą niepewnością prowadzenia działalności na rynku zagranicznym, zostały one bardzo wysoko ocenione przez przedsiębiorców. Jest to wynik zgodny z teorią kosztów transakcyjnych, w której szczególnie akcentowana jest rola niepewności jako cechy determinującej charakter transakcji (Williamson, 1998).

Drugim ważnym źródłem z 43,5\% odsetkiem wskazań są trudności w znalezieniu partnera na rynku zagranicznym. Odsetek wskazań był w tym przypadku o ponad 20 punktów procentowych mniejszy niż przy pierwszej wybranej przyczynie, jednak odpowiedź na to pytanie potwierdza, jak ważnym problemem dla przedsiębiorców prowadzących sprzedaż na eksport jest pozyskanie partnera.

Kolejne często wskazywane źródła powstawiania kosztów transakcyjnych są ze sobą powiązane i dotyczą konieczności poznania wymagań i wprowadzenia pewnych dostosowań: 37,3\% firm wskazało odmienne regulacje prawne, 33,4\% konieczność dostosowania produktów do odmiennych wymogów rynku zagranicznego, a 21,2\% odmienne gusty klientów. Odwołujac się do teorii kosztów transakcyjnych, można zauważyć, że prowadzone z związku z nimi czynności wiążą się $\mathrm{z}$ zaangażowanymi $\mathrm{w}$ transakcję aktywami. Konieczność wprowadzenia dostosowań zarówno w przedsiębiorstwie, jak i w jego produktach, prowadzi do zwiększenia ich specyficzności.

Następne trzy źródła można połączyć w jedną grupę, ponieważ wszystkie wiążą się z trudnościami operacyjnymi. Zaliczają się do nich „skomplikowane procedury/ dokumentacja związana z eksportem" wskazane przez $24,2 \%$ przedsiębiorstw, „trudności w dostepnie do informacji o rynku zagranicznym" - 15,2\% oraz „bariera kulturowa i językowa”-11,1\%. Sa one już jednak zdecydowanie mniej ważne w ocenie przedsiębiorstw.

Co ciekawe, jedynie $9,1 \%$ badanych przedsiębiorstw jako źródło powstawania kosztów transakcyjnych wskazało „występowanie barier taryfowych". Można to tłumaczyć faktem, iż wśród rynków eksportowych dominują rynki krajów UE, gdzie w handlu nie występują bariery taryfowe.

\section{Wnioski}

Przeprowadzona analiza pokazuje, że koszty transakcyjne nie tylko odgrywaja role w wyborze formy ekspansji, ale też wiążą się z często analizowanymi w literaturze barierami rozwoju ekspansji. Pokonywanie tych barier wymaga ponoszenia pewnych kosztów. Świadomość istnienia tych kosztów i umiejętnego kształtowania może wpływać na przebieg internacjonalizacji. Oddziaływanie wszystkich zidentyfikowanych przez Williamsona czynników, które wpływają na kształtowanie kosztów transakcyjnych, staje się silniejsze, gdy przedsiębiorstwo wchodzi na zagraniczne rynki. Głównych źródeł wzrostu kosztów transakcyjnych można upatrywać w dwóch grupach czynników: związanych z dystansem psychicznym oraz z większą niepewnością prowadzenia działalności na rynku zagranicznym. Wyniki badań pokazuja, że dla przedsiębiorstw szczególnie ważna jest druga grupa czynników. Ograniczenie negatywnego wpływu wzoru kosztów transakcyjnych na ekspansję wymagałoby przede wszystkim podejmowania działań ograniczajacych oddziaływanie rosnacego na skutek ekspansji ryzyka.

Przedstawione badania pokazują jedynie najważniejsze źródła powstawania kosztów transakcyjnych. Dla lepszego zrozumienia roli kosztów transakcyjnych jako bariery ekspansji ważne byłoby przeprowadzenie dalszych analiz: jak postrzeganie kosztów transakcyjnych wpływa na gotowość firmy do podjeccia ekspansji i jej rozwoju, w jaki sposób determinuje wybór rynków, jakie jest jego oddziaływanie na powodzenie realizowanej strategii internacjonalizacji. 


\section{Footnote}

1 Badanie ilościowe przeprowadzone w $2009 \mathrm{r}$. - otrzymano zwrot 99 ankiet. Szacuje się, że próba objęła od 5 do $10 \%$ działających w Polsce przedsiębiorstw branży spożywczej prowadzących działalność eksportową.

\section{Bibliografia}

Abdel-Latif, A.M. i Nugent, J. (1996). Transaction cost impairments to international trade: Lessons from Egypt. Contemporary Economic Policy, 14(2), $1-14$.

Al-Aali, A. (1995). Obstacles Facing Saudi Arabian Food And Chemical Exporters. International Jour nal of Commerce and Management, 5(3), 17-31, http://dx.doi.org/10.1108/eb047311

Alchian, A.A. i Demsetz, H. (1972). Production, Information Costs, and Economic Organization. The American Economic Review, 62(5), 777-795.

Anastassopoulos, G. i Traill, W.B. (1998). Determinants of Foreign Entry Strategies in Greek Food Industry. Agribusiness, 14(4), http://dx.doi. org/10.1002/(SICI) 1520-6297(199807/08)14:4 \%3C267::AID-AGR2\%3E3.3.CO;2-2, s. 270.

Arrow, K.J. (1985). Granice organizacji. Warszawa: PWN.

Aulakh, P.S., Jiang, M.S. i Pan, Y. (2010). International technology licensing: Monopoly rents, transaction costs and exclusive rights. Journal of International Business Studies, 41, 587-605, http:// dx.doi.org/10.1057/jibs.2009.19.

Barker, A.T. i Kaynak, E. (1992). An Empirical Investigation of the Differences Between Initiating and Continuing Exporters. European Journal of Marketing, 26(3).

Barnes, B.R., Chakrabarti, R. i Palihawadana, D (2006). Investigating the export marketing activity of SMEs operating in international healthcare markets. Journal of Medical Marketing, 6(3), 209-221.

Brouthers, K.D. (2002). Institutional, cultural and transaction cost influences on entry mode choice and performance. Journal of International Business Studies, 33(2), http://dx.doi.org/10.1057/palgrave. jibs. 8491013 .

Brouthers, K.D. (2013). A retrospective: Institutional, cultural and transaction cost influences on entry mode choice and performance. Journal of International Business Studies, 44, http://dx.doi. org/10.1057/jibs.2012.23.

Byford, L. i Henneberry, D. (1996). Export Decisions of Food Processing Firms in Kansas, Missouri, and Oklahoma. Agribusiness, 12(3), 247-264.

Coase, R.H. (1937). The nature of the firm. Economica, November, 386-405, http://dx.doi.org/ $10.2307 / 2626876$
Czinkota, M. (1996). Why national export promotion. International Trade Forum, 2, 10-15.

Dunning, J.H. (2006). Toward a new paradigm of development: implications for the determinants of international business. Transnational Corporations, 15(1).

Eriksson, K., Johanson J., Majkgard, A. i Sharma, D. (1997). Experiental knowledge and cost in the internationalization process. Journal of International Business Studies, 28(2), 337-360.

Fischer, Ch. (2004). Managing International Trade of Food Products: A Survey of German and Australian Companies. Agribusiness, 20(1).

Furubotn, E.G. i Richter, R. (2005). Institutions and economic theory: the contribution of the new institutional economics. Ann Arbor: The University of Michigan Press, 48-57.

Gorynia, M. i Mroczek, K. (2013). Koszty transakcyjne jako determinanta formy zagranicznej ekspansji przedsiębiorstwa, Ekonomista, 2, 201.

Geyskens, I., Steenkamp, J.-B. i Kumar, N. (2006). Make, Buy or Ally: A Transaction Cost Theory Meta Analysis. Academy of Management Journal, 49(3), http://dx.doi.org/10.5465/AMJ.2006.21794670.

Gruszecki, T. (2002). Wspótczesne teorie przedsiębiorstwa. Warszawa: Wydawnictwo Naukowe PWN

Hardt, Ł. (2006). Narodziny i ewolucja treści znaczeniowej wyrażenia „koszt transakcyjny. Gospodarka Narodowa, 11-12.

Hennart, J.F. (2010). Transaction Cost Theory and International Business. Journal of Retailing, 86(3), 257-269, http://dx.doi.org/10.1016/j.jretai. 2010.07.009.

Kasiewicz, S. (2004). Przesłanki i cele tworzenia przedsiębiorstwa. W: S. Kasiewicz i H. Możaryn (red.), Teoria przedsiębiorstwa. Wybrane zagadnienia. Warszawa: Oficyna Wydawnicza SGH.

Kim, L., Nugent, J.B. i Seung-Jae Yhee (1997). Transaction costs and export channels of small and medium-sized enterprises: the case of Korea. Contemporary Economic Policy, 15(1), 104-120, http:// dx.doi.org/10.1111/j.1465-7287.1997.tb00458.x.

Klaes, M. (2000). The birth of the concept of transaction costs: Issues and controversies. Industrial and Corporate Change, 9(4), 569, http://dx.doi. org/10.1093/icc/9.4.567.

Klein, S., Frazier, G.L. i Roth, V.J. (1990). A Transaction Cost Analysis Model Of Channel Integration In International Markets. Journal of Marketing Research, 27(2), 196-208, http://dx.doi. org/10.2307/3172846.

Leonidou, L.C. (2004). An Analysis of the Barriers Hindering Small Business Export Development. Journal of Small Business Management, 
42(3), 279-302, http://dx.doi.org/10.1111/j.1540627X.2004.00112x

Leonidou, L.C. i Katsikeas, C.S. (1996). The export development process: An integrative review of empirical models. Journal of International Business Studies, 27(3), 517-551.

Milgrom, P. i Roberts, J. (1992). Economics, organization and management. Englewood Cliffs, New Jersey: Prentice Hall.

Mroczek, K.D. (2014). Transaction Costs in Institutional Environment and Entry Mode Choice. International Journal of Social, Behavioral, Educational, Economic and Management Engineering, 8(4).

North, D.C. (1994). Institutions, institutional change and economic performance. Cambridge: Cambridge University Press, http://dx.doi.org/10.1017/ CBO9780511808678.

Peng, M.W. i York, A.S. (2001). Behind intermediary performance in export trade: Transactions, agents, and resources. Journal of International Business Studies, 32(2), 327-346, http://dx.doi. org/10.1057/palgrave.jibs.8490955.

Rao, P.K. (2003). The economics of transaction costs. Palgrave Macmillan.

Reid, S. (1983). Firm Internationalization, Transaction Costs And Strategic Choice. International Mar keting Review, 1, http://dx.doi.org/10.1108/eb008251.

Richman, D.B. i Macher, J. (2006). Transaction Cost Economics: An Assessment of Empirical
Research in the Social Science. Duke Law School Working Paper Series, Paper 62, http://dx.doi. org/10.2139/ssrn.924192.

Rymarczyk, J. (2004). Internacjonalizacja i globalizacja przedsiębiorstwa. Warszawa: PWE.

Schroath, F.W. i Korth, C.M. (1989). Managerial Barriers to the Internationalization of U.S. Property and Liability Insurers Theory and Perspectives. Journal of Risk and Insurance, 56(4), 630-649.

Singh, S. (1996). International Marketing of AgroFood Products by Developing Country Firms Some Conceptual Issues. Agribusiness, 12, 99-103.

Szymański, W. (2011). Zmiany kosztów transakcyjnych w dostosowaniu przedsiębiorstw do wyzwań współczesnej gospodarki. W: R. Sobiecki i J.W. Pietrewicz (red.), Koszty transakcyjne - skutki zmian dla przedsiębiorstw. Warszawa: Oficyna Wydawnicza SGH.

Wang, N. (2003). Measuring Transaction Costs: An Incomplete Survey, referat prezentowany na Conference on Transaction Costs, Ronald Coase Institution, 21-23 lutego, Chicago, Illinois, USA, www. coase.org (05.12.2007).

Williamson, O.E. (1989). Transaction cost economics. W: R. Schmalensee, Handbook of industrial organization. New York: Elsevier Science.

Williamson, O.E. (1998). Ekonomiczne instytucje kapitalizmu: firmy, rynki, relacje kontraktowe. Warszawa: Wydawnictwo Naukowe PWN. 